\title{
Microcellular foamed aromatic polyamides (aramids). Structure, thermal and mechanical properties.
}

Blanca S. Pascual, ${ }^{1}$ Miriam Trigo-López, ${ }^{1}$ Cipriano Ramos, ${ }^{2}$ María Teresa Sanz, ${ }^{2}$ Jesús L. Pablos, ${ }^{3}$ Félix C. García, ${ }^{1}$ José A. Reglero Ruiz ${ }^{* 1}$ and José Miguel García ${ }^{1}$

1 Departamento de Química, Facultad de Ciencias, Universidad de Burgos, Plaza de Misael Bañuelos s/n, 09001 Burgos, Spain. Tel: +34 947258 085; Fax: +34 947258831.

2 Departamento de Biotecnología y Ciencia de los Alimentos, Área de Ingeniería Química, Facultad de Ciencias, Universidad de Burgos, Plaza de Misael Bañuelos s/n, 09001 Burgos, Spain. Tel: +34 947258 085; Fax: +34 947258831 .

3 Instituto de Ciencia y Tecnología de Polímeros, Consejo Superior de Investigaciones Científicas, ICTP-CSIC, Juan de la Cierva 3, 28006 Madrid, Spain.

${ }^{*}$ Corresponding author Email: jareglero@ubu.es

Abstract

We have deeply diminished the density of high performance aromatic polyamides or aramids. Thus, we have prepared microcellular films that at the same time maintain the outstanding thermal and mechanical properties characteristic of these high performance materials. Two different cellular aramids were produced, based on commercial poly $(m-$ phenylene isophthalamide), one of them with an additional azide group. Microcellular structures have been obtained by adding ionic liquids combined to $\mathrm{ScCO}_{2}$ foaming process, with cell sizes between 0.6 and $4.7 \mu \mathrm{m}$ and cell densities between $10^{9}-10^{11}$ cells $\mathrm{cm}^{3}$. The density was lowered for the commercial poly(m-phenylene isophthalamide) (Nomex® and Teijin Conex®) from 1.43 to $0.62 \mathrm{~g} \cdot \mathrm{cm}^{-3}$ and from 1.48 to $0.31 \mathrm{~g} \cdot \mathrm{cm}^{3}$ for the aramid containing the azide group. Foams present the following thermal and mechanical properties: $5 \%$ weight loss observed at $T>400{ }^{\circ} \mathrm{C}$ and relative Young modulus and tensile strength of $1.2 \mathrm{GPa} \cdot\left(\mathrm{g} \cdot \mathrm{cm}^{-3}\right)^{-1}$ and $60 \mathrm{MPa} \cdot\left(\mathrm{g} \cdot \mathrm{cm}^{-3}\right)^{-1}$, respectively.

Keywords: aramids ; microcellular ; ionic liquids ; $\mathrm{ScCO}_{2}$ foaming ; polyamide ; 


\section{Introduction}

Aromatic polyamides, or aramids, are high performance materials characterized by their outstanding mechanical properties and by their superior thermal resistance. High value added goods are prepared with aramid-fibers, such as advanced human-protection clothing, high-temperature isolation paper and advanced composites. [1] The success of commercial aramids, namely poly(m-phenylene isophthalamide) (MPIA) (main brand names: Nomex® and Teijin Conex®) and poly(p-phenylene terephthalamide) (PPTA) (main brand names: Kevlar $\AA$ and Twaron $\AA$ ), relay on their thermal and mechanical behavior and also on their low density compared with other inorganic fibers, carbon fiber, ceramics and metals. [2] This is especially important in aeronautic and automotive industry, but also in human protection clothing to prepare lightweight and high strength materials.

For the sake of lowering weight, the foaming of metals and polymers is a topic of current interest, [3,4] and this is especially true for aramids, where preparation of foamed aramids has not been reported.

Cellular materials, especially cellular polymers or polymer foams, have been analyzed during several decades due to their unique combination of thermal, mechanical and acoustical properties with low weight. [5] In the last years, efforts have been carried out in the production of cellular polymers with controlled morphology, to obtain polymer foams with specific properties that can be easily fabricated in industrial processes for different applications. Polymer foams can be described in terms of their density, average cell size and cell density. In case of microcellular polymers, they are characterized for having average cell size between 1 and $100 \mu \mathrm{m}$, with cell densities in the range of $10^{6}$ $10^{10}$ cells $\cdot \mathrm{cm}^{-3}$. Reducing the cell size below $1 \mu \mathrm{m}$ originates sub-micro cellular foams, with cell densities above $10^{11}$ cells $\cdot \mathrm{cm}^{-3}$. The reduction of the cell size has gained a lot of interest, producing, for example, super-isolating materials or polymers with ultra-low dielectric properties. [6,7]

The use of supercritical $\mathrm{CO}_{2}\left(\mathrm{ScCO}_{2}\right)$ as green foaming agent has revealed as the most promising technique to obtain polymer foams with controlled morphology. [8,9] Regarding engineering polymers, different approaches have been employed to improve both the $\mathrm{CO}_{2}$ absorption and their foaming capability. One of these research lines is focused in the use of ionic liquids (ILs) due to the good compatibility combined to the enhancement of $\mathrm{CO}_{2}$ absorption. [10-15] 
Combining all the previous ideas, the main objective of this work was filling the lack of microcellular aramids, foaming them with $\mathrm{ScCO}_{2}$ using ILs as $\mathrm{CO}_{2}$ absorption promoters. $[16,17]$

\section{Experimental}

\subsection{Materials and instrumentation}

1-allyl-3-methylimidazolium chloride ( $\geq 97 \%$ ) was used as ionic liquid (IL). N,Ndimethylacetamide (DMAc, $99 \%$ ) was employed as solvent to obtain the polyamide films. Both chemicals were purchased from Sigma-Aldrich and used as received. The rest of the materials employed to synthetize the raw polyamides can be found in our previous work [18].

Thermogravimetric analysis data of the polyamide films were recorded on a TA Instrument Q50 TGA analyzer, whereas Differential Scanning Calorimetry (DSC) measurements were carried out in a DSC Q200 TA Instruments equipment.

Foaming took place in a single-step batch process using $\mathrm{ScCO}_{2}$. Films were saturated in a high-pressure reactor of $2 \mathrm{~L}$ of capacity, at a controlled pressure and temperature. After saturation, depressurization took place by opening a manual valve placed at the top of the reactor.

Cellular structural determination of the microcellular films was carried out in a scanning electron microscopy model JEOL JSM-6460LV.

Finally, the tensile tests of the polyamide films were performed on a SHIMADZU EZ Test Compact Table-Top Universal Tester. Mechanical clamps were using a gauge length of $9.44 \mathrm{~mm}$.

\subsection{Synthesis of aromatic polyamides and preparation of films}

Aromatic polyamides PA1 and PA2 were prepared and purified following the procedures described in our previous work [19]. Also, in polyamide PA2, the reactive azide group introduced into the structure leads to a crosslinking effect following a simple an inexpensive heat treatment, $\left(240^{\circ} \mathrm{C}\right.$ during $\left.10 \mathrm{~min}\right)$. 
To prepare the polyamide films with ionic liquids a simple procedure was followed: $0.2 \mathrm{~g}$ of PA1 or PA2 was dissolved in $2.85 \mathrm{~mL}$ of DMAc and stirred until full dissolution of the polyamide. Then, $50 \%$ weight percent (wt.) of the ionic liquid is added to the solution and stirred for an additional hour. The mixture is then filtered off and cast in a glass placed inside an air-circulating oven at $60^{\circ} \mathrm{C}$ for 12 hours.

Three different groups of non-foamed films were fabricated. A first group of films without ionic liquid, a second group with $50 \%$ wt. of ionic liquid, and a third group of films in which the ionic liquid was eliminated in distilled water during $24 \mathrm{~h}$, to also evaluate the influence of the ionic liquid in the mechanical and thermal properties.

\section{$2.3 \mathrm{ScCO}_{2}$ foaming process}

Foaming took place in a single-step batch process using $\mathrm{ScCO}_{2}$. Films were cut in pieces of $40 \times 40 \mathrm{~mm}^{2}$, and sandwiched between 2 square steel plates $\left(50 \times 50 \mathrm{~mm}^{2}\right.$ and $2 \mathrm{~mm}$ thickness), to confine the gas during depressurization, thus limiting the gas diffusion process outside the material. Films were saturated in the high-pressure reactor at 35 $\mathrm{MPa}$ and $60^{\circ} \mathrm{C}$ during $8 \mathrm{~h}$. Depressurization was carried out using a manual opening valve, with a depressurization time of about $10 \mathrm{~s}$.

\subsection{Cellular characterization and density determination}

Films were frozen in liquid nitrogen, fractured and gold coated in vacuum to assure the electrical conductivity of the films. Cellular structural characterization determining the average bubble radius from SEM images, measured using the Image ${ }^{\circledR}$ software, raccounting the number of bubbles in each image $n_{i}$ and its radius $R_{i}$. The average radius $\bar{R}$ is calculated from Equation 1:

$$
\bar{R}=\frac{\sum_{i=1}^{N} n_{i} R_{i}}{\sum_{i=1}^{N} n_{i}}
$$

where $N$ represents the bubble count. Five different SEM images were analyzed from each material, averaging the data. The estimation of the cell density $N_{c}$ was calculated using the Kumar's approximation, according to Equation 2:

$$
N_{c}=\left(\frac{n}{A}\right)^{3 / 2}
$$


where $n$ is the number of cells in the image and $A$ is the area of the image.

Taking into account the average radius value and cell density, the gas volume fraction $V_{f}$ was obtained using Equation 3:

$$
V_{f}=\frac{\pi \bar{d}^{3} N_{c}}{6}
$$

, where $\bar{d}$ is the average diameter. Then, gas volume fraction $V_{f}$ and foam density $\rho^{S E M}$ are related throughout Equation 4, in which $\rho_{s}$ is the solid material density:

$$
V_{f}=1-\frac{\rho^{S E M}}{\rho_{S}}
$$

\subsection{Thermal properties}

Differential scanning calorimetry (DSC) was performed to evaluate the thermal transitions of the materials. Tests were carried out following a four-cycle procedure. First, after 5 min of stabilization at $30^{\circ} \mathrm{C}$, films were heated up to $350^{\circ} \mathrm{C}$ at $20^{\circ} \mathrm{C} \cdot \mathrm{min}^{-1}$. Then, after 5 min of stabilization at $350{ }^{\circ} \mathrm{C}$, films were cooled down to RT at the same rate. Third, a second heating cycle was performed following the same conditions of the first cycle, concluding with a final cycle to cool down the samples to RT at $20^{\circ} \mathrm{C} \cdot \mathrm{min}^{-1}$. All the tests were performed under $\mathrm{N}_{2}$ atmosphere (flow rate $50 \mathrm{ml} \cdot \mathrm{min}^{-1}$ ). Mass of the films was fixed at approximately $20 \mathrm{mg}$ in each test.

The thermal stability was determined by thermogravimetric analysis (TGA). Films were first dried in vacuum overnight at $40{ }^{\circ} \mathrm{C}$, and then TGA tests were performed under $\mathrm{O}_{2}$ atmosphere using the next procedure: First, films were heated from RT to $100{ }^{\circ} \mathrm{C}$ at 10 ${ }^{\circ} \mathrm{C} \cdot \mathrm{min}^{-1}$, and then kept during $5 \mathrm{~min}$ to eliminate the moisture content. Finally, TGA analysis was completed by heating up to $800{ }^{\circ} \mathrm{C}$ at $10{ }^{\circ} \mathrm{C} \cdot \mathrm{min}^{-1}$. Additionally, the crosslinking effect of PA2 was analyzed performing a TGA following the conditions of the crosslinking process. PA2 was heated from RT to $100^{\circ} \mathrm{C}$ at $10^{\circ} \mathrm{C} \cdot \mathrm{min}^{-1}$, then kept during $5 \mathrm{~min}$, and heated up to $240{ }^{\circ} \mathrm{C}$ at $10^{\circ} \mathrm{C} \cdot \mathrm{min}^{-1}$. Crosslinking process was performed by keeping the sample at $240^{\circ} \mathrm{C}$ during $10 \mathrm{~min}$, and then the analysis was completed by heating up to $800^{\circ} \mathrm{C}$ at $10^{\circ} \mathrm{C} \cdot \mathrm{min}^{-1}$. Samples were weighted approximately at $10 \mathrm{mg}$. 


\subsection{Tensile tests}

Low velocity tensile tests $\left(5 \mathrm{~mm} \cdot \mathrm{min}^{-1}\right)$ were performed in the microcellular films to evaluate the influence of cells in different mechanical parameters (Young's modulus and stress and deformation at break point). 5 strips of $5 \mathrm{~mm}$ width and $40 \mathrm{~mm}$ length were tested for each film, averaging the data.

\section{Results and discussion}

Two different aromatic polyamides were casted into films and foamed. One of the aramids is the commercial MPIA (PA1) and the other one a functional MPIA containing an azide group in the main polymer chain (PA2) that allows for the crosslinking of the materials, after foaming, for superior thermal and mechanical performance (Scheme 1). $[18,19]$ The foaming was achieved by using conventional $\mathrm{ScCO}_{2}$ foaming procedure. The influence of the ILs and the crosslinking process is investigated in terms of the cellular structure, mechanical and thermal properties.<smiles>[X]C(C)(C)Nc1cccc(NC(=O)c2cccc(C(C)(C)C)c2)c1</smiles>

PA1<smiles>[Y][Y9]=[W]</smiles>

Scheme 1. Chemical structure of the synthetized polyamides.

Two dense aromatic polyamide films were prepared by casting, F_PA1 and F_PA2, which had conventional densities for aramids. Also, two films were prepared having 50 $\%$ wt. of the ionic liquid 1-allyl-3-methylimidazolium chloride, namely F_50PA1/50IL and F_50PA2/50IL. It is important to remark that in a preliminary study, different ionic liquids added in several proportions were tested, but not foaming in $\mathrm{ScCO}_{2}$ was observed in samples with proportions of ionic liquids below $50 \%$ wt. Thus, a fixed proportion of 50 $\%$ wt. was employed using this specific ionic liquid. 
The removal with water of the IL from these films rendered the films F_50PA1/50IL-R and F_50PA2/50IL-R. Surprisingly, these films prepared with IL showed low density. We expected low density of the films upon foaming with $\mathrm{ScCO}_{2}$ and not before. The films gave rise themselves to microcellular materials, explained by a phase inversion upon entering into contact with water of the atmosphere after taking them out of the oven. The reason was clear after analyzing the morphology of the films by SEM (Figure 1), were a microcellular structure was observed for films F_50PA1/50IL and F_50PA2/50IL. Next, the removal of the ionic liquid through the immersion of the film in distilled water during $24 \mathrm{~h}$, films F_50PA1/50IL-R and F_50PA2/50IL-R, causes the development of new pores and a reduction of the average cell radius, thus increasing the cell density. Thus, it was possible to obtain an initial microcellular structure just by using the ILs before the $\mathrm{ScCO}_{2}$ treatment (we will denote these films as non-foamed films). This could be explained by a thermally induced phase separation process, which has been classically employed to produce porous membranes. [20]
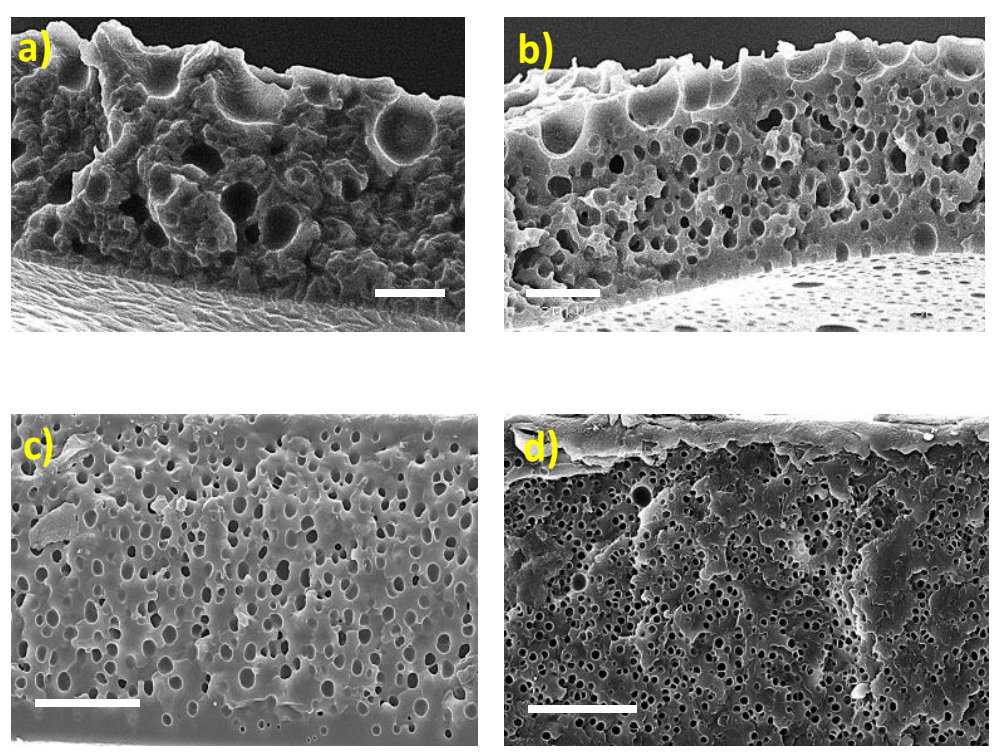

Figure 1. SEM micrographs of: a) F_50PA1/50IL; b) F_50PA1/50IL-R; c) F_50PA2/50IL; d) F_50PA2/50IL-R. Bar scale $10 \mu \mathrm{m}$.

Then, further treatment with $\mathrm{ScCO}_{2}$ of films with ILs render foamed materials with even a more interesting morphology. We present in Figure 2 the SEM micrographs of all the foamed aramid films, before and after the removal of the ionic liquid. It can be seen that all aramid films present a very homogeneous structure, observing a closed-cell structure in the case of polymers derived from PA1 (Figures 2a) and 2b)) and an open-cell structure for materials prepared from PA2 (Figures 2c) and 2d)). It is also evidenced that removing the ionic liquid does not affect significantly to the microcellular structure, 
when comparing Figure 2a) with Figure 2b) (Films (F_50PA1/50IL)f and $\left.\left(F \_50 P A 1 / 50 I L-R\right)_{f}\right)$, and also Figure 2c) with Figure 2d) (Films (F_50PA2/50IL) $f$ and $\left.\left(F \_50 P A 2 / 50 I L-R\right)_{f}\right)$. Finally, the heating of $F_{-}(50 P A 2 / 50 I L-R)_{f}$ at $240{ }^{\circ} \mathrm{C}$ for $10 \mathrm{~min}$ render the crosslinked foam $\left(F \_50 P A 2 / 50 I L-R\right)_{f}{ }^{c}($ See Figure 2e)). [19]
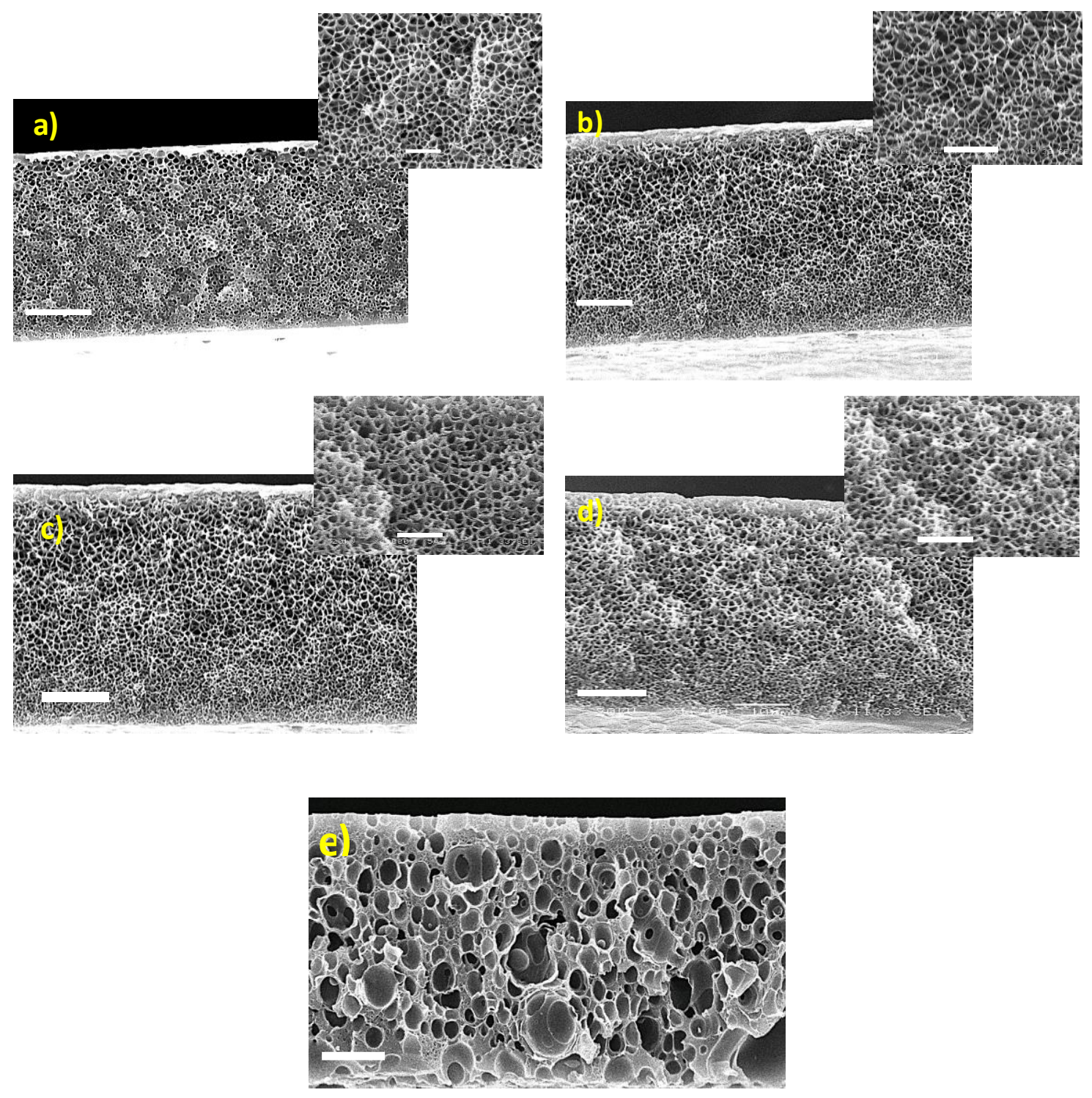

Figure 2. SEM micrographs of the foamed films based on PA1 and PA2. a) $\left(F \_50 P A 1 / 50 I L\right)_{f}$; b) (F_50PA1/50IL-R $)_{f}$; c) (F_50PA2/50IL $)_{\mathrm{f}}$; d) $\left(\mathrm{F} \_50 \mathrm{PA} 2 / 50 \mathrm{IL}-\mathrm{R}\right)_{\mathrm{f}}$; e) (F_50PA2/50IL-R) $)_{\mathrm{f}}^{\mathrm{c}}$. Bar scale: $10 \mu \mathrm{m}$ in all figures, and $5 \mu \mathrm{m}$ in zoomed regions of figures a), b) c) and d).

Table 1 describes the nomenclature and morphological parameters calculated of all the films. The density values estimated from the morphological parameters $\left(\rho^{S E M}\right)$ are in the same order of magnitude, with a small overestimation, that the density measured experimentally from the dimensions and weight of the films $(\rho)$. This indicates that the 
calculation of average cell radii and cell density can be considered acceptable. On the other hand, it is important to remark that the value of $\rho^{S E M}$ is very dependent of the value of the average radii $\bar{R}$.

\begin{tabular}{|c|c|c|c|c|c|c|}
\hline Films & $\begin{array}{c}\rho \\
\left(\mathrm{g} \cdot \mathrm{cm}^{-3}\right)\end{array}$ & $\begin{array}{c}e \\
(\mu m)\end{array}$ & $\begin{array}{c}\bar{R} \\
(\mu m)\end{array}$ & $\begin{array}{c}N_{C} \\
\left(\mathrm{cells} \cdot \mathrm{cm}^{-3}\right)\end{array}$ & $V_{f}$ & $\begin{array}{l}\rho^{S E M} \\
(\mu m)\end{array}$ \\
\hline F_PA1 & 1.43 & 27 & $\mathrm{n} / \mathrm{a}$ & $\mathrm{n} / \mathrm{a}$ & $\mathrm{n} / \mathrm{a}$ & $\mathrm{n} / \mathrm{a}$ \\
\hline F_PA2 & 1.48 & 35 & $\mathrm{n} / \mathrm{a}$ & $\mathrm{n} / \mathrm{a}$ & $\mathrm{n} / \mathrm{a}$ & $\mathrm{n} / \mathrm{a}$ \\
\hline F_50PA1/50IL & 0.84 & 68 & $4.7 \pm 2.1$ & $8.0 \cdot 10^{9}$ & 0.29 & 0.95 \\
\hline F_50PA2/50IL & 0.50 & 37 & $3.2 \pm 1.2$ & $4.9 \cdot 10^{9}$ & 0.16 & 0.64 \\
\hline F_50PA1/50IL-R & 0.71 & 68 & $3.8 \pm 0.4$ & $4.3 \cdot 10^{9}$ & 0.37 & 0.83 \\
\hline F_50PA2/50IL-R & 0.39 & 45 & $3.0 \pm 0.2$ & $6.0 \cdot 10^{10}$ & 0.23 & 0.53 \\
\hline F_(50PA1/50IL)f & 0.72 & 77 & $0.9 \pm 0.1$ & $1.9 \cdot 10^{11}$ & 0.48 & 0.78 \\
\hline$F_{-}(50 \mathrm{PA} 2 / 50 \mathrm{IL}) \mathrm{f}$ & 0.43 & 41 & $0.7 \pm 0.1$ & $5.4 \cdot 10^{11}$ & 0.38 & 0.46 \\
\hline$F_{-}(50 P A 1 / 50 I L-R)_{f}$ & 0.62 & 75 & $0.9 \pm 0.1$ & $5.9 \cdot 10^{11}$ & 0.58 & 0.69 \\
\hline$F_{-}(50 P A 2 / 50 I L-R)_{f}$ & 0.32 & 53 & $0.6 \pm 0.1$ & $7.4 \cdot 10^{11}$ & 0.50 & 0.44 \\
\hline$F_{-}(50 P A 2 / 50 I L-R)_{f^{c}}$ & 0.31 & 53 & $3.3 \pm 1.6$ & $4.4 \cdot 10^{9}$ & 0.51 & 0.42 \\
\hline
\end{tabular}

Table 1. Morphological parameters of films calculated using the ImageJ® software.

Considering the density values, it is reduced between two and five times respect to the density of dense polyamide films. For example, density of $F_{-}(50 P A 2 / 50 I L-R)_{f}$ and $F_{-}(50 P A 2 / 50 \mathrm{IL}-\mathrm{R})_{\mathrm{f}}^{\mathrm{c}}$ is about $0.3 \mathrm{~g} \cdot \mathrm{cm}^{-3}$, whereas the density of PA2 is close to $1.5 \mathrm{~g} \mathrm{~cm}^{-}$ $3^{3}$, thus reaching a density reduction of around 5 times. As expected, it is also observed that removing the ionic liquids reduces the foam density from values of $0.72 \mathrm{~g} \cdot \mathrm{cm}^{-3}$ to $0.62 \mathrm{~g} \cdot \mathrm{cm}^{-3}$ in the case of PA1 and from $0.43 \mathrm{~g} \cdot \mathrm{cm}^{-3}$ to $0.32 \mathrm{~g} \cdot \mathrm{cm}^{-3}$ in the case of PA2.

Films foamed with $\mathrm{ScCO}_{2}$ showed reduced average cell size compared with non-foamed films, with cell sizes in the sub-microcellular range $\left(\bar{R}<1 \mu \mathrm{m}, \mathrm{N}_{\mathrm{c}} \approx 10^{11}\right.$ cells $\left.\cdot \mathrm{cm}^{-3}\right)$. Also, these materials showed open-cell structure with cell sizes bellow $1 \mu \mathrm{m}$, while non-foamed films had closed cells. The crosslinking, $F_{-}(50 \mathrm{PA} 2 / 50 \mathrm{IL}-\mathrm{R})_{\mathrm{f}}^{\mathrm{c}}$, increase the average cell size compared to non-crosslinked foamed film, F_(50PA2/50IL-R)f, probably due to the evolution of nitrogen gas in the crosslinking process.

The key parameters of aramids are the thermal and the mechanical behavior. Thermal properties were evaluated through differential scanning calorimetry (DSC) and 
thermogravimetric analysis (TGA). Regarding the thermal resistance, as derived from thermogravimetric data obtained under oxidizing atmosphere (temperatures at which 5 $\%$ and $10 \%$ of weight loss, $T_{5} \%$ and $T_{10} \%$, measured in synthetic air), the excellent performance of commercial and synthetic aramids is maintained, with $5 \%$ and $10 \%$ weight loss observed about 430 and $450{ }^{\circ} \mathrm{C}$ for dense and cellular materials. Glass transition temperatures were determined from DSC measurements, as exposed in Figures S1 and S2 in Section S1.1 of the Electronic Supplementary Information (ESI). Additionally, the TGA curves can be found in Figures S3 and S4 from Section S1.2 of the ESI.

Tensile tests data is presented in Table 2. In relation to the mechanical behavior of the cellular films, in terms of Young's moduli $(E)$ and stress at break point $\left(\sigma^{b p}\right)$, the microcellular films have lower values than the dense films. However, if density is considered and relative Young's moduli $\left(E_{r}\right)$ and stress determined $\left(\sigma^{b p} r\right)$, excellent mechanical data are obtained for the cellular materials. Thus, $E_{r}$ and $\sigma^{b p} r$ values higher than 1200 and $85 \mathrm{MPa} \cdot\left(\mathrm{g} \cdot \mathrm{cm}^{-3}\right)^{-1}$, respectively, are obtained for the microcellular films. It is also observed that the treatment with $\mathrm{ScCO}_{2}$ deeply improves the mechanical performance, especially considering the $E_{r}$ values, which are increased twice respect to non-foamed films, which is probably with the higher homogeneity of the cellular morphology (Figures 1 and 2). Also, the additional crosslinking increases drastically the value of $E_{r}$ up to $1400 \mathrm{MPa} \cdot\left(\mathrm{g} \cdot \mathrm{cm}^{-3}\right)^{-1}$, showing a better mechanical performance than dense films. Some of the obtained stress-strain curves can be found in Figures S5 to S7 in Section S1.3 of the ESI, in which, for example, the plasticization effect of the IL is clearly shown, leading to a poor mechanical behavior in films F_50PA1/50IL and F_50PA2/50IL compared to foamed films (F_50PA1/50IL-R $)_{f}$ and $\left(F \_50 P A 2 / 50 I L-R\right)_{f}$ (See comparative curves in Figures S5 and S7 in the ESI).

\begin{tabular}{ccccc} 
Films & $\begin{array}{c}T_{5} \% \\
\left({ }^{o} \mathrm{C}\right)\end{array}$ & $\begin{array}{c}T_{10 \%} \\
\left(^{\circ} \mathrm{C}\right)\end{array}$ & $\begin{array}{c}E_{r} \\
M P a \cdot\left(\mathrm{g} \cdot \mathrm{cm}^{-3}\right)^{-1}\end{array}$ & $\begin{array}{c}\sigma_{b p}{ }^{r} \\
M P a \cdot\left(\mathrm{g} \cdot \mathrm{cm}^{-3}\right)^{-1}\end{array}$ \\
\hline F_PA1 & 434 & 452 & $1231 \pm 47$ & $53 \pm 4$ \\
F_PA2 & 433 & 453 & $1075 \pm 34$ & $55 \pm 5$ \\
F_50PA1/50IL-R & 431 & 453 & $649 \pm 61$ & $77 \pm 4$ \\
F_50PA2/50IL-R & 433 & 451 & $558 \pm 39$ & $87 \pm 5$ \\
F_(50PA1/50IL-R) $)_{f}$ & 428 & 454 & $1093 \pm 61$ & $49 \pm 5$ \\
F_(50PA2/50IL-R) $)_{f}$ & 431 & 452 & $1215 \pm 67$ & $59 \pm 6$
\end{tabular}




$$
\text { F_(50PA2/50IL-R) })^{c} \quad 404 \quad 428 \quad 1421 \pm 71 \quad 65 \pm 7
$$

Table 2. Thermal and mechanical behavior of the films.

\section{Conclusions}

In summary, we have reported novel microcellular high performance aromatic polyamide materials. The microcellular materials are prepared in a green fashion using ionic liquids and supercritical $\mathrm{CO}_{2}$. We obtained homogeneous open-cell sub-micro size cellular foams, cell-size below $1 \mu \mathrm{m}$, with densities up to 5 times lower than the original material and comparable thermal and mechanical properties in terms of their outstanding behavior. The procedure can be used to prepare microcellular materials based on other high-performance condensation aromatic polymers.

\section{Acknowledgments}

The financial support provided by FEDER (Fondo Europeo de Desarrollo Regional) and the Spanish Agencia Estatal de Investigación (MAT2017-84501-R) is gratefully acknowledged.

\section{Funding}

This research did not receive any specific grant from funding agencies in the public, commercial, or not-for-profit sectors.

\section{References}

[1] J.A Reglero Ruiz, M. Trigo-López, F.C. García, J.M. García, Functional aromatic polyamides, Polymers. 9 (2017) 414(1)-414(44). https://doi.org/10.3390/polym9090414. [2] M. Trigo-López, J.M. García, J.A. Reglero, F.C. García, R. Ferrer, Aromatic polyamides, in: H.F. Mark (Ed.), Encyclopedia of Polymer Science and Technology, John Wiley \& Sons, Inc., New Jersey, 2018, pp. 1-51.

[3] L.J. Lee, C.C. Zeng, X. Cao, X.M. Han, J. Shen, G.J. Xu, Polymer nanocomposite foams, Compos. Sci. Technol. $65 \quad$ (2005) 2344-2363. https://doi.org/10.1016/j.compscitech.2005.06.016. 
[4] J. Banhart, Manufacture, characterization and applications of cellular metals and metal foams, Prog. Mater. Sci. 46 (2001) 559-632. https://doi.org/10.1016/S00796425(00)00002-5.

[5] N. Mills, Polymer Foams Handbook: Engineering and Biomechanics Applications and Design, first ed., Butterworth-Heinemann, UK, 2007.

[6] S. Liu, J. Duvigneau, J. Vancso, Nanocellular polymer foams as promising high performance thermal insulation materials. Eur. Polym. J. 65 (2015) 33-45. https://doi.org/10.1016/j.eurpolymj.2015.01.039.

[7] B. Notario, J. Pinto, R. Verdejo, M.A. Rodríguez-Pérez, Dielectric behavior of porous PMMA: From the micrometer to the nanometer scale, Polymer. 2016, 107, 302-305. https://doi.org/10.1016/j.polymer.2016.11.030.

[8] A.I. Cooper, Porous materials and supercritical fluids, Adv. Mater. 16 (2003) 10491059. https://doi.org/10.1002/adma.200300380.

[9] A.I. Cooper, Polymer synthesis and processing using supercritical carbon dioxide, J. Mater. Chem. 10 (2000) 207-234. https://doi.org/10.1039/A906486I.

[10] J.L. Pablos, N. García, L. Garrido, J. Guzmán, F. Catalina, T. Corrales, P. Tiemblo, Highly efficient mixed. Li+transport in ion gel polycationic electrolytes, J. Membr. Sci, 545 (2018) 133-139. https://doi.org/10.1016/j.memsci.2017.08.073.

[11] H. Zhang, J. Wu, J. Zhang, J. He, 1-Allyl-3-methylimidazolium chloride room temperature ionic liquid: A new and powerful nonderivatizing solvent for cellulose, Macromolecules. 38 (2005) 8272-8277. https://doi.org/10.1021/ma0505676.

[12] I. Jha, M. Bisht, P. Venkatesu, Does 1-Allyl-3-methylimidazolium chloride act as a biocompatible solvent for stem bromelain?, J. Phys. Chem. B. 120 (2016) 5625-5633. https://doi.org/10.1021/acs.jpcb.6b03912.

[13] Y. Yuan, J. Wang, N. Fu, S. Zang, Hydrolysis of cellulose in 1-allyl-3methylimidazolium chloride catalyzed by methyltrioxorhenium, Catal. Commun. 76 (2016) 46-49. https://doi.org/10.1016/j.catcom.2015.12.024.

[14] J. Cota, F. Fernández Martínez, Recent advances in the synthesis and applications of metal organic frameworks doped with ionic liquids for $\mathrm{CO}_{2}$ adsorption, Coord. Chem. Rev. 351 (2017) 189-204. https://doi.org/10.1016/j.ccr.2017.04.008.

[15] A. Wilke, J. Yuan, M. Antonietti, J. Weber, Enhanced carbon dioxide adsorption by a mesoporous poly(ionic liquid), ACS Macro Lett. 1 (2012) 1028-1031. https://doi.org/ $10.1021 / \mathrm{mz} 3003352$.

[16] S. Siripurapu, R.J. Desimone, S.A. Khan, J.M. Spontak, Low-temperature, surfacemediated foaming of polymer films, Adv. Mater. $16 \quad$ (2004) 989-993. https://doi.org/10.1002/adma.200306068. 
[17] S. Siripurapu, J.M. DeSimone, S.A. Khan, R.J. Spontak, Controlled foaming of polymer films through restricted surface diffusion and the addition of nanosilica particles or $\mathrm{CO}_{2}$-philic surfactants, Macromolecules. $38 \quad$ (2005) 2271-2278. https://doi.org/10.1021/ma047991b.

[18] M. Trigo-López, J.L. Barrio-Manso, F. Serna, F.C. García, J.M. García, Crosslinked aromatic polyamides: A further step in high-performance materials, Macromol. Chem. Phys. 214 (2013) 2223-2231. https://doi.org/10.1002/macp.201300342.

[19] M. Trigo-López, J.L. Pablos, F.C. García, F. Serna, J.M. García, Functional aramids: Aromatic polyamides with reactive azido and amino groups in the pendant structure, Polym. Chem. 52 (2014) 1469-1477. https://doi.org/10.1002/pola.27141.

[20] P. van de Witte, P.J. Dijkstra, J.W.A. Van den Berg, J. Feijen, Phase separation processes in polymer solutions in relation to membrane formation, J. Membrane Sci. 117 (1996) 1-31. https://doi.org/10.1016/0376-7388(96)00088-9. 